\title{
Happiness and Invulnerability from Chance: Western and Eastern Perspectives
}

\author{
Johannes M.M.H. Thijssen and David R. Loy
}

\begin{abstract}
Since the beginning of Western philosophy, thinkers have discussed how one might lead a good, i.e. a happy, life and what role luck plays in flourishing. According to one dominant Ancient Greek tradition, life's circumstances are not relevant for our happiness, and, moreover, they fall outside of our control. What is up to us is how we respond to life's circumstances and adversities. Christianity, however, rejected ancient tradition and moved happiness to a new home: heaven. Because Adam and Eve were disobedient in Paradise, God punished the human species with a 'genetic' defect which made life miserable for each and every individual. Chance or (bad) luck is an inevitable ingredient of human suffering. Buddhism also perceives chance or luck as intrinsic to life, but locates it into the sphere of human control. It is not the gods, but we, who, through our own actions, are responsible for what happens to us. This is called the law of karma: we reap what we have sown. There are striking parallels between the Greek methods to train our mental responses to (bad) luck and the Buddhist analysis of unwholesome actions and corresponding advice to improve our karma. Both traditions are still helpful today in our attempts to secure happiness in the face of chance adversity.
\end{abstract}

\section{Introduction}

On 17 July 2014, Malaysian Airlines flight MH 17 departed from Amsterdam. It never reached its destination in Kuala Lumpur; the plane crashed in the Ukraine, not far from the Russian border, claiming 298 lives. A few days after the crash, a Dutch newspaper ran a story about a family that had 'miraculously' missed flight

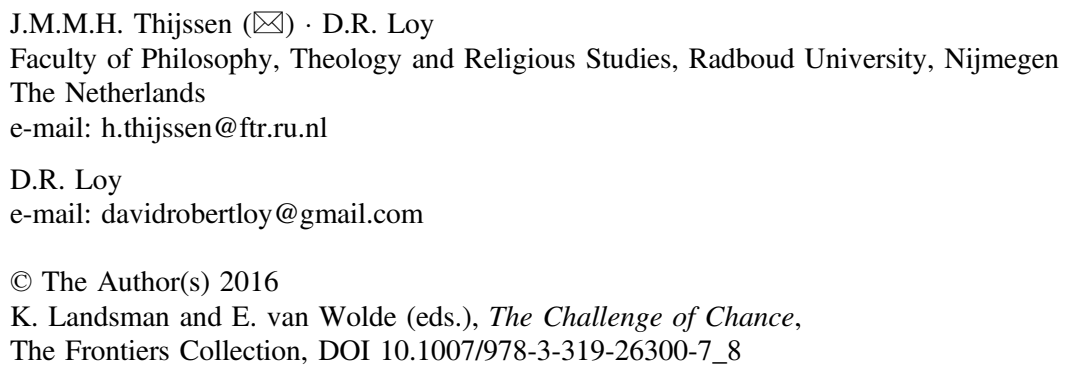


MH 17. The family had arrived slightly late at Schiphol Airport and, as the flight was overbooked, had been transferred to another flight.

In the summer of 2005, Hurricane Katrina swept the Gulf of Mexico coast from central Florida to Texas. At least 1833 people were killed, most of them in New Orleans. The storm caused $\$ 108$ billion in damage, depriving many people of their homes and possessions.

These examples are just two of many others that people tend to associate with 'luck', 'chance', or 'karma', by those familiar with the Buddhist term. Initially, the family that arrived late would feel they were unlucky in missing flight MH 17. But after the crash the reverse was true; apparently they had been extremely lucky or they had good karma Likewise, the people whose homes lay in the path of hurricane Katrina and lost their homes and lives were clearly unfortunate while those who lived a mile out of the path were just lucky.

What do we mean when we attribute a plane crash or a hurricane to chance or (bad) luck? It means that we feel these events are random, unlikely and the result of conjunctions of causes that are unknown to us. These events are unpredictable: there is no apparent purpose or plan which includes all causal chains. Moreover, and more importantly for this chapter, these events appear to be beyond our control. Chance events expose the vulnerability of our happiness and even our lives. One moment we are prosperous and happy, and the next moment our lives are disrupted and our happiness is shattered.

In some languages, the words happiness and luck have an etymological connection. For example, in German and Dutch, the same word is used for 'chance' and 'happiness,' thus implying that it takes some measure of luck (Glück; geluk) to achieve happiness (Glück; geluk). In English, there is also an etymological connection. In Middle-English 'hap' means 'luck' or 'chance,' and also occurs in 'happiness.' Yet is happiness only a matter of luck? How much good luck can be expected and how much bad luck must be endured in attempts to lead a good life? How insecure is our happiness?

Socrates and Siddharta Gautama, who later came to be known as the Buddha, were near contemporaries. The philosophical traditions they initiated were anchored in existential questions about how to live well, i.e. how to end suffering and be happy. Interestingly, early Indian Buddhist philosophers as well as early Western philosophers reflected on the relationship between chance and leading a happy life. We look at ancient Greek and Buddhist philosophies and Christianity to explore how they developed ways of thinking to get to grips with the terrifying notion of life based on chance.

According to contemporary Western thinking, which is heavily influenced by Greek notions, Hurricane Katrina and flight MH 17 appear to be chance events or occurrences of (bad) luck. Even though there is a connection between certain actions and certain consequences, for instance, between having bought a ticket and being on flight MH 17, the actions and interactions are far too many and far too complicated to be able to distinguish any direct causal chains. This is what, for instance, Aristotle meant by tuche, by luck: when a man goes to the marketplace and runs into a debtor that he wished, but did not expect to find, their meeting is a result, not of a 
determinate cause, but of luck (Physics II.5). Similarly, the travellers did not board flight MH 17 expecting to die. That it happened was the outcome of (bad) luck.

In her now classic The Fragility of Goodness, Martha Nussbaum has drawn attention to many Greek philosophers' preoccupation with luck. ${ }^{1}$ Their concern was to find out how a person might lead a good, i.e. happy, life and become immune to bad luck. As will be explained below, the Western approach is to learn how to cope mentally with the undesirable results of luck in the pursuit of happiness.

Buddhist philosophy would take a different view of a plane crash or a hurricane and attribute the devasting effects to the karma of the victims: as if the misfortune happened through the victims own agency, instead of, just happening. A western response to this view might be: "What terrible deeds have the victims done in the past to deserve Katrina or flight MH 17?" It is true that the term 'karma' is central to the Buddhist analysis of human action and seems to suggest a responsibility for whatever is happening to us. Karma, however, is not a calculus of rewards and punishments for one's actions. In the words of Jay Garfield, it is not "a cosmic bank account". ${ }^{2}$ Nevertheless, many of the events in one's life are seen to be due to one's karma, i.e. they are the result of previous actions, whether in this or a former life. According to traditional Buddhist teachings, the quality of an action is determined both by the intentions behind it and by its consequences. This includes many, perhaps most, of the good and bad things that happen to us, Thus, mere chance is abolished and, although it may be delayed, we retain a way to control what happens to us by behaving in a wholesome way. In this chapter, we try to compare and contrast Western Greek and Asian Buddhist attitudes towards chance and how chance events impact on happiness.

\section{Ancient Greek Philosophy as a Way of Life: The Pursuit of Happiness}

The distinguished British philosopher Bernard Williams once quipped: "The legacy of Greece to Western philosophy is Western philosophy"! ${ }^{3}$ And indeed, there is a continuity between ancient and contemporary philosophy. Not only does philosophy continually refer to themes that originated in antiquity, but philosophers today remain fascinated by the views and theories of ancient Greeks and Romans. Yet, at the same time, Williams's aphorism overlooks one crucial aspect of ancient Western philosophy that has disappeared from contemporary academic philosophy. Philosophy today is mainly a theoretical and conceptual discourse, whereas ancient philosophy crucially involved a way of life.

\footnotetext{
${ }^{1}$ Nussbaum (1986), although her angle is different from the one taken here.

${ }^{2}$ Garfield (2015), 284. See also Loy (2008).

${ }^{3}$ Williams (2006), 3 .
} 
Ancient philosophy covers a lengthy period of time, which conventionally runs from the appearance of Thales in the sixth century B.C. until 529 C.E. when Emperor Justinian, under pressure from a local Christian group, closed the philosophical school in Athens. Durig this long period of twelve centuries, philosophy was initially situated within a Greek culture and then continued within a Roman context. Greek was the main language of the philosophers. When we study the earliest Western philosophy, we tend to see it through the lens of contemporary philosophical perspectives, and thus discover an ancient science, logic, ethics, metaphysics and even a philosophy of mind. Due to this fragmentation, we tend to miss the overall character of philosophy at that time, which runs through the diversity and heterogenity of views and schools. In his Philosophies for sale, the satirist Lucian (c. AD 125-180) wittily captures the heart of ancient philosophy. ${ }^{4}$ In a marketplace, Hermes is setting up stalls for selling philosophies, with prices that vary considerably. Each philosopher represents a specific school along with the life-style, the bios, that comes with it, and is loudly advertised by Hermes. These philosophies are attractve to buyers because they are guides for living a good life.

Yet what does this mean about philosophy as the search for wisdom and truth, an inquiry into all kinds of topics and problems as well as the art of analysis and argumentation? The first Western philosophers were engaged in those activities as well, but in addition, and in contrast to philosophers nowadays, they also lived their philosophy. They operated on the (tacit) assumption that philosophy can save your life. Philosophy is an authoritative guide on how to live, since the knowledge of the world and your place in it will motivate you to live your life accordingly. In sum, the philosophical life is a life based on reasoning, but it is about more than reasoning.

The French scholar Pierre Hadot, more than anyone else, has drawn attention to the ancient conception of philosophy as a way of life, and has emphasized its existential and spiritual dimensions. ${ }^{5}$ Philosophical discourse was an integral part of a specific way of life. It was meant to justify and disseminate the way to live, both among followers and opponents. At the same time, philosophical discourse also expressed a way of life. And finally, it functioned as a type of mental exercise or spiritual practice.

With Plato, this conception of philosophy came to be firmly established in all the different schools. The most prominent among them were Plato's own Academy, Aristotle's Lyceum, the Stoa, Epicurus's Garden and the Skeptics. ${ }^{6}$ The last school criticized the other schools for clinging to theories and statements (dogmata), whose truth remained open to doubt, and hence to further investigation. According

\footnotetext{
${ }^{4}$ References to ancient texts are according to the standard system. Unless otherwise stated, the editions of the Loeb Classical Library (Cambridge, MA-London) have been used for Greek and Latin texts and their English translations. Lucianus' edition of his Biôn Praksis and its translation are in vol. II, 450-511 of his works.

${ }^{5}$ Hadot (1995), which has been translated into several languages, among which English in Hadot (2002).

${ }^{6} \mathrm{~A}$ convenient recent introduction to the philosophical schools in antiquity, which, moreover, has been inspired by Hadot's studies is Cooper (2012).
} 
to the Skeptics, the most sensible view is to assume that truth is beyond our powers, a claim that in itself should not be taken as a dogmatic statement. The schools were not just groups of pupils or followers who identified with a particular teacher, but were also physically located in certain places: for instance, at a gymnasium outside the walls of Athens, at a painted collonade in the marketplace, or in a garden.

In his studies, Hadot has emphasized the role of 'spiritual exercises' (askêsis, meletê) in each school. The earliest Western philosophers were mental athletes who through their practical exercises, which were part of their way of life, tried to transform themselves spiritually. Hadot took his inspiration from the title of Ignace of Loyola's famous Spiritual exercises (Exercitia spiritualia), which in his view were nothing but a Christian continuation of Greek and Roman practices. ${ }^{7}$ Mental training takes place according to a method that is independent from any theory, and hence is applicable to any theory. The purpose of the method is to 'digest' the specific doctrines, and thus prepare the practitioner for a life-change. Among the exercises that Hadot has explored are diet, meditation on the breath, dialogue and discussion between master and pupil, the study of maxims, self-examination and self-mastery. One such exercise, familiar to anyone who ever studied for an exam, consists of writing summaries or lists of key concepts and memorising them. Epicurus wrote special summaries (epitomai) for the sake of his pupils. The Stoic Epictetus compared the process of digesting such material with the mastication of food. In sheep, the digestion of food will produce milk and wool, whereas the digestion of philosophical propositions will lead to a change of behaviour (Encheiridion, 46). Marcus Aurelius claimed that from the repetition of Stoic views the soul, like a garment, will receive a new color (Meditationes, 5.16). Epicurus's encouragement to become accustomed to the idea that death is nothing to us, since we will not be aware of our own death, is also a type of spiritual exercise (Letter to Menoikeus, 124). It can diminish our desire to be immortal and hence help us to enjoy our mortal life.

In view of Hadot's heightened awareness of ancient philosophy as a way of life, as a program for-self-improvement-through-exercise, his virtually complete omission of the purpose of philosophy is remarkable. The philosophical schools had the ambition to contribute to the happiness (eudaimonia) of their adherents.

Ancient philosophers had a keen eye for the human propensity to seek happiness. ${ }^{8}$ As Plato points out: "We all strive to be happy" (Euthydemus 282a). The desire to be happy is so evident that it does not make sense to ask "Why do you wish to be happy?" (Symposium 205a). Happiness is an end-in-itself and hence does not need further justification. Moreover, being happy means that you are doing well $(\mathrm{eu}$ prattein), and finally, happiness implies the presence of good things and the absence of bad things in your life. All these characteristics of eudaimonia are taken up in the traditions after Plato and further elaborated-in particular the question

\footnotetext{
${ }^{7}$ Hadot (2002).

${ }^{8}$ Throughout this article, eudaimonia has been translated as 'happiness,' and eudaimôn as 'happy.' See also Long (1996), 181-84 and (2001), 33-34. The Greek texts also use makarios (happy) and makariotês (happiness), which recur in the New Testament, and are often translated as blessed. See for instance The Gospel of Matthew, 5, 2-10. See also note 17.
} 
which ingredients in a human life contribute to happiness and which ones are obstacles. Ancient philosophy is motivated by the concern to help us lead a life that is worth living, a life that flourishes (eu prattein). In the words of Aristotle:

.....let us say what it is that we say political expertise seeks, and what the topmost of all achievable goods is. Pretty well most people are agreed about what to call it: both ordinary people and people of quality say 'happiness', and suppose that living well and doing well are the same thing as being happy (Ethica Nicomachea 1095a17-20). ${ }^{9}$

Once you realize that the goal in your life is to become happy, you have to bring order to your life and make important choices. You do not want to end up with a life that is 'unlived', which consists of merely killing time. So what is the best possible life? In other words, how can one really become happy? Each school offered its own vision of the nature of the world and the human condition, and built its own way of life upon those insights.

Human beings are vulnerable: not only the playthings of desires and emotions, but also exposed to social and physical circumstances beyond their control, such as untrustworthy rulers, wars, poverty, disease and obscurity that can all be described as 'bad luck'. All these factors can be obstacles to happiness and thus a source of suffering. How much do such circumstances affect one's quest for happiness? Although different philosophical schools provided different anwers, their approaches were all based on the revolutionary idea that human beings are (or can be) masters of their own happiness. Happiness is achievable for anyone. Happiness is what you think, and you can learn to think by doing philosophy!

In one of his tragedies, Euripides (480-406 B.C.) asks the following important question:

"O Zeus, what should I say? That you watch over men? Or that you have won the false reputation of doing so, while chance (tuchê) in fact governs all mortal affairs?" (Hecuba II, 488-91)

The play is about the former queen of Troy. After its fall, Hecuba had become a Greek slave and as the story unfolds she will learn about the death of her two children. The idea that we are governed by gods may seem disconcerting to some, but the idea that we are living in a world that was not made for us, ruled by random chance and constant change, may be even more frightening.

\section{Immunising Against Luck: Ancient Greek Approaches}

Since ancient times, Greek poets and philosophers have struggled with the role of tuchê, luck or chance, in human life, including how to avert bad tuchê: how to avoid one's life turning into a tragedy. Seeking support from the gods seemed one sensible strategy. Yet the gods behave in erratic ways and are difficult to control.

\footnotetext{
${ }^{9}$ Aristotle. Nicomachean Ethics (2002).
} 
Furthermore, our misfortunes may have been caused not by us, but by what our ancestors did. In the story of Pandora's box, the poet Hesiod explains how the miseries and misfortunes of humankind originated. Before Pandora lifted the lid of the storage jar "the tribes of men used to live upon the earth entirely apart from evils, and without grievous toil and distressful diseases, which gave death to men" (Hesiod, Works and Days, 90-93).

The philosophical response to Euripides' question was offered by Plato. He gave an entirely new twist to an already extant term: eudaimonia and, moreover, was the first to bring up whether chance (tuchê) is also one of the good things that we need in order to become happy (Euthydemus, 279c). The original meaning of eudaimonia is that one is favored by the gods. A person who is eudaimôn has a 'good (eu) daimon,' usually an identified Olympic God, and hence is in possession of the good things that such a daimon is supposed to provide. Yet how can one guarantee to be favored by the gods, who in the myths appear to be as capricious as human beings? One can try to please them with sacrifices and prayers, but in the end we still have to surrender to the disconcerting idea that our happiness, our eudaimonia, depends on (good) luck (tuchê): we have no control over the gods.

Plato's brilliant move was to internalize the daimon. ${ }^{10}$ Within us, we have a godlike capacity: our reason. By putting oneself under the rule of reason, one still submits to a god, though now an internal one. Be master of your own life by following your reason. Only by using our rationality can we become happy, i.e. temporarily becoming like a god (homoiôsis theôi). ${ }^{11}$ If you live according to reason, life does not have to turn into a tragedy, run by blind luck and change. That is the novel powerful reply that Plato gives to the literary tradition.

By making happiness dependent upon our rational capacities, Plato opens the door for reconsidering the influence of external circumstances that seem to depend on luck, and that is exactly what the various schools did. Philosophers since Plato have not taken recourse to pacifying the gods, but have instead developed other ways of thinking to make themselves immune to contingencies and the inherent vulnerability of human existence. The ancient schools developed strategies to eliminate the power of ungoverned tuche, of the impact of external circumstances beyond our control. In this chapter, the emphasis will be on those schools that are based on the insight that, although we cannot change the world, we can change our mental attitude if we are willing to commit to a certain way of life. ${ }^{12}$ In what follows, we shall briefly focus on three such strategies that were meant to make our

\footnotetext{
${ }^{10}$ See Long (2001) and also Mikalson (2002).

${ }^{11}$ Plato, Timaeus $90 \mathrm{a}-\mathrm{c}$ and also Theaetetus $176 \mathrm{a}-\mathrm{b}$. That the gods are happy, is mentioned by Plato, Symposium 202c7. See Sedley (1999) for a fundamental discussion of becoming like a god.

${ }^{12}$ In his Nicomachean Ethics Aristotle discusses the two extreme views about the influence of luck on human happiness. According to one position, being happy is a matter of good luck; it is a gift from the gods. The other position claims that the factors relevant to happiness are within the agent's control. The strategy of the advocates of this view is to make happiness invulnerable to luck. Aristotle himself takes a middle course. See Nussbaum (1986): 318-342.
} 
happiness safe from luck. Unfortunately, there is not the space here to elaborate all the theoretical details and intricacies, so we will confine ourselves to an outline. ${ }^{13}$

One common obstacle to happiness is not getting what we desire, for success in acquiring what we want is never guaranteed. So we need to be careful about what we desire. According to Epicurus, human beings are led by pleasure (hedonê) and pain (lupê). These 'instincts' determine what we choose and what we avoid. Unfortunately, human beings are often confused in their judgments about what they want. Epicurus provides an intelligent classification of human desires, and an analysis of the beliefs upon which they depend. Very few desires turn out to be natural and necessary, such as those for food, drink and sex. Most desires are unnecessary, because we are too much affected by habitual preferences. It is not really necessary to eat filet mignon every day. And finally, some desires are empty, because they are based on wrong ideas, such as the wish to become famous or wealthy. These desires are not important for our pleasure and happiness. Those who are capable of satisfying their natural desires are free from pain (aponia) and mental distress (ataraxia), and, as a consequence, they are happy (eudaimôn).

A second obstacle to happiness is emotional distress caused by our reactions to (random) circumstances. The Stoics developed strategies to manage our emotions (pathê). Their basic idea is that the happy life is a life of virtuous activity, i.e. a life in which one's actions and behaviour are an expression of the virtues (such as justice, magnamity, temperance, courage). According to the Stoic conception, our usual emotions are often a result of social conditioning, and are, in fact, ways of feeling born out of ignorance. The Stoics are particularly concerned about unskillful emotions. Not fear in response to real danger, but anxiety, desire, anger, grief, obsessive love and jealousy are the targets of their therapy, because those emotions disturb our lives, and, consequently, threaten our happiness. They are erroneous value judgments. By revising or 'unlearning' these value judgments, we can learn to see things differently.

According to the Stoics, we are caught in a dualism between the pursuit of what we believe is good and the avoidance of what we think to be bad. However, only the virtues are really good, and only the vices are really bad. The persons or situations that give rise to emotions are actually not, on Stoic theory, important for our happiness. We tend to judge them as 'good' or 'bad', whereas they are 'indifferent', or neutral. The benefits equal the harms. The Stoics encourage us with various exercises that keep our emotions from getting a hold on us. It is "up to us" how we interpret and respond to whatever happens to us. In this way, Stoic philosophy can shield us from misfortune: we learn not to be affected by whatever happens. We are free from emotions (apatheia). How the Stoic immunisation against bad luck works can be seen, for instance, in the following advice from Epictetus:

\footnotetext{
${ }^{13}$ The following studies are extremely useful for understanding these aspects of ancient philosophy: Annas (1993), Cooper (2012), Long (1996) and (2006), Nussbaum (1994), Sorabji (2000), Tsouma (2009) and Warren (2009).
} 
Some things are up to us and others are not. Up to us are opinion, impulse, desire, aversion, and, in a word, whatever is our own action. Not up to us are body, property, reputation, office, and, in a word, whatever is not our own action. The things that are up to us are by nature free, unhindered and unimpeded; but those that are not up to us are weak, servile, subject to hindrance, and not our own. Remember, then, that if you suppose what is naturally enslaved to be free, and what is not your own to be your own, you will be hampered, you will lament, you will be disturbed, and you will find fault with both gods and men. But if you suppose only what is your own to be your own, and what is not your own not to be your own (as is indeed the case), no one will ever coerce you, no one will hinder you, you will find fault with no one, you will accuse no one, you will not do a single thing against your will, you will have no enemy, and no one will harm you because no harm can affect you (Encheiridion, 1) ${ }^{14}$

Epictetus's advise is neatly summarized in the following well-known, but hard-gained advice:

Do not ask things to happen as you wish, but wish them to happen as they do happen, and your life will go smoothly (Encheiridion, 8 )

A third obstacle is addressed by the Skeptics. They also wish to free us from the dualism of good and bad. We think that we are struck by bad circumstances, and we pursue the things that we believe are good, but which we lack. Once we have acquired these so-called good assets, we are afraid to lose them, and, as a consequence, experience troubles "For those who hold the opinion that things are good or bad by nature are perpetually troubled" (Sextus Empiricus, $P H$ 1.27). ${ }^{15}$ Their strategy was to carefully investigate (skepsis) the various arguments and theories of the different schools. Since this inquiry remained inconclusive, it led to a suspension of judgement about the 'real' nature of things. It is not possible to affirm or deny anything about a matter under investigation. We can talk only about appearances, without arriving at the truth. Nevertheless, such skeptical inquiry has beneficial effects: "But those who make no determination about what is good and bad by nature neither avoid nor pursue anything with intensity; and hence they are tranquil" Sextus Empiricus, $P H$ 1.28).

By not entertaining fixed views about the nature of things or a situation, the level of one's anxiety is not unnecessarily raised. The Skeptic experiences hunger and thirst, yet does not add the value judgement that it is really unfortunate that this is happening to her, of all people. ${ }^{16}$ To use a Zen metaphor: she does not place another head upon her own head. The goal of the Skeptic is to attain peace of mind or tranquility (ataraxia) towards situations that are a matter of opinion or appearance, and maintain composure (metriopatheia) towards situations that are inevitable (PH 1.25). Once we have suspended judgement, freedom from confusion will follow "as a shadow follows a body" (PH 1.29).

\footnotetext{
${ }^{14}$ The Epictetus translations are taken from Epictetus (1995).

${ }^{15}$ The Sextus Empiricus translations are taken from Annas and Barnes (1994).

${ }^{16}$ See also Sextus Empiricus, $P H$ 3.235-238 and M 11.110-167.
} 
In such ways these earliest Western philosophers responded to the human motivation to become happy. Moreover, they were all concerned to make happiness immune from chance events beyond our control. Their important message is that it is a matter of ignorance to think that to live a happy life is due to circumstances beyond one's control. Rather, it is a matter of how we deal with those circumstances. This insight, and living according to this insight, requires training. We cannot eliminate suffering, but it is up to us whether it will make us unhappy. It all depends on the perspective that we have on the world and on ourselves. Philosophy has an important role to play in providing us with this perspective, as Epictetus points out:

Philosophy does not promise to secure anything external for man, otherwise it would be admitting something that lies beyond its proper subject-matter. For as the material of the carpenter is wood, and that of the statuary bronze, so the subject-matter of the art of living is each person's own life (Dissertationes I.15.2)

The terms a-taraxia, a-ponia and a-patheia are significant. The schools promise that after a thorough training, they can free us from several kinds of mental suffering: from confusion, from pain, and from unskillful emotions. In this way, our happiness will become invulnerable to the world. The Skeptics are concerned to free us from the suffering that arises when we get entangled in opposing views and theories; the Epicurians teach us to learn what we really want, to analyse our desires and not to desire more than you need; the Stoics help us to see our emotional responses for what they really are: upheavals of thought that alternate between the poles of attraction and aversion.

\section{A Christian Perspective: The Myth of the Fall}

Christianity brought a total change of scene. In particular Augustine does not believe in the human capacity to achieve long-term happiness here and now and in the role which ancient philosophers claimed to help achieve it. ${ }^{17}$

But such is the stupid pride of these men who suppose that the supreme good is to be found in this life and that they can be the agents of thir own happiness, that their wise men,-I mean the man whom they describe as such with astounding inanity,- whom, even if he be blinded and grow deaf and dumb, lose the use of his limbs, be tortured with pain, and visited by every other evil of the sort that tongue can utter or fancy conceive, whereby he is driven to inflict death on himself, they do not scruple to call happy (De civitate dei, XIX, 4).

Augustine presents Christianity as an alternative philosophy in the ancient sense of a way of life. Becoming Christian now comes to be the sure route to happiness, though not in this life. In one of his most famous works, The City of God

\footnotetext{
${ }^{17}$ Augustine uses beatus (happy) and beatitudo (happiness), which are translations of makarios and makariotês, respectively.
} 
(De civitate dei), written between 412 and 426/27, Augustine presents his complex vision of earthly life and contrasts it with eternal life in the heavenly Jerusalem. ${ }^{18}$ Book 19 is devoted to the philosophers' pathetic attempts to attain happiness within the misery of human life (De civitate dei 19.1).

Those who think that there is any happiness in this world, reveal their astonishing lack of understanding. According to Augustine, even the rhetorically gifted are not able to describe life's miseries to any extent. This does not prevent Augustine from offering a page-long complaint about human suffering due to not getting what we want, losing what we have, ailments, decay, mental illness, and the incessant strife between virtue and evil. The best we can do in this life, is to foster hope for happiness in the future, i.e. after our death (De civitate dei 19.4). We should not overlook that Augustine's keen eye for human suffering was sharpened by a civil war and the invasion of Germanic tribes. In 410, Alaric and his Goths sacked Rome, the eternal city. Its impact was much greater than that of $9 / 11$ in the West. From the Augustinian perspective, bad luck is just part of human life. However, from the perspective of God, there is no luck or randomness. God is all-powerfull, just, has complete knowledge, and hence, is in total control. So, the question of how to deal with luck did not arise for Augustine. His concern rather is to explain the miseries of human life in view of a God who is neither weak, nor unjust.

So how do we explain and deal with humankind's misfortunes? Augustine offers an ingenious interpretation of the Book of Genesis, which becomes a fundamental Christian doctrine in both its Catholic and Protestant versions. ${ }^{19}$ The only explanation that Augustine can think of is that our suffering in this life is a punishment from God. A punishment not for something we did, but a punishment for the disobedience of Adam and Eve in the Garden of Eden. Augustine's story is based on his reading of Genesis 2:18-3:24. God had explicitly forbidden the first humans to eat from the tree of knowledge of good and evil. However, a fallen angel, using a snake as its instrument, started with "the weakest link of the human couple" and seduced Eve to eat from its fruit; and Eve offered the fruit to Adam. Obviously, God discovered their disobedience and punished them with expulsion from Paradise, and hence from eternal life and happiness. Suddenly, mankind found itself in a hostile world, in which it had to toil for a living and was inflicted with bodily decay and death. The blissfull order between soul and body was destroyed. The disobedience of Adam and Eve to God has been punished with another corresponding disobedience: the human body is no longer under control of the will, as is clear both from inconvenient sexual temptation and from unwanted failure to perform (De civitate dei 14.17). God has punished us with concupiscentia carnis, with carnal desire. It is

\footnotetext{
${ }^{18}$ See, for instance, Van Oort (1991).

${ }^{19}$ Nisula (2012) is the most fundamental recent study on the topic, which focuses on sexual desire (concupiscentia) as the key concept in Augustine's theory. Augustine's theory is also discussed in Nelson (2011). Among the many studies published about Augustine, see further Brown (1969) Chadwick (2009) and Rist (1994) for details about his life and the broader intellectual background of his views.
} 
this disobedience of Adam and Eve to God, which tainted them with a weakness that has been passed on to future generations. One contemporary opponent, Julian of Aeclanum, consistently described Augustine's position as peccatum naturale, a natural defect or sin. The disorder of sexual desire (concupiscentia) disseminates itself, so to speak, in the off-spring and thus becomes 'genetic'. ${ }^{20}$

As in Hesiod's story, Augustine too believes that our misfortunes are caused by what our ancestors did. There is no way to escape our miserable life on earth. Only after it ends may we become eternally happy, if we follow the Christian way of life and if God grants us his grace. In the hands of Augustine, Christianity's solution to the indifference of chance came to be its abolishment: God has total control and complete knowledge. At the divine dimension, there is no contingency, whereas at the human level, chance or (bad) luck are part of human suffering and have to be accepted as God's severe, but just punishment for Adam and Eve's disobedience. They are part of God's plan.

\section{The Asian Buddhist Perspective: Karma Rather than (Bad) Luck}

Buddhism, lacking ruling gods or a creator God, removes the intermediary between our moral actions and their results. Karma (Pali, kamma) is understood as an impersonal law of the cosmos: our intentional acts are causes that have direct effects, sooner or later, in that what we do rebounds back onto us. ${ }^{21}$ Again, however, as in Christianity, the horrifying specter of mere chance is abolished. Although the consequences of our actions may be delayed, we have a handle on what will happen to us in the future. Insofar as we continue to be reborn, our present circumstances are a result of what we have done earlier, and our future circumstances will be a result of what we are doing now. The doctrine of karma offers an explanation for the repeated suffering of human beings. It stretches out the cause and effect process over several lifetimes and thus makes acceptable that the vicious are not punished immediately and the virtuous may suffer like Job in this life. However, not original sin, but a spiritual ignorance lies at the origin of suffering. Nothing happens to us by chance or luck, but as the result of our karma. According to the Buddhist view, we are 'heir' to our actions, as Peter Harvey puts it. We reap what we have sown, although not everything that happens to us is caused by karmic actions in the past. $^{22}$

For Augustine, happiness here on earth is not possible, yet if we obey God's will we can hope for an eternity in heaven after we die. But what can we do according to the Buddhist view to diminish our suffering and to contain what seems to happen to

\footnotetext{
${ }^{20}$ See Nisula (2012), chapter three and especially 127-134 with the relevant texts in the footnotes.

${ }^{21}$ See also Loy (2008) and the excellent introductions in Carpenter (2014) and Harvey (2013).

${ }^{22}$ Harvey (2013), 39-40.
} 
us by (bad) luck? By following the Buddha's teachings, we can end our ignorance and improve our karma. The foundation of these teachings is the doctrine of the "Four Noble Truths" and the related Buddhist analysis of the roots of unskilful or unwholesome actions. In what follows, we will present a brief overview of these crucial elements of Buddhist thought

For early Buddhism the ultimate goal is nirvana (nibbana in Pali), but the nature of that goal is less clear. This world of samsara is a realm of suffering (Sanskrit duhkha, Pali dukkha), craving, and delusion; nirvana signifies the end of them, because it is the end of rebirth and karmic retribution. According to the earliest texts we have, in the Pali Canon, Sakyamuni the historical Buddha stated that he taught only dukkha and how to end it, but apparently he offered few positive descriptions of the goal. ${ }^{23}$ Then is someone who has attained nirvana happy? Despite occasional references to sukha (the Pali term that corresponds most closely to the English term happiness, but which also can be translated as comfort or ease), the emphasis in the Buddhist tradition has been more on serenity and peace of mind.

Perhaps it is not surprising, then, that lay Buddhists have often been less interested in attaining nirvana-which requires thousands of lifetimes of hard practice, according to the common understanding - than in "merit-making" that will lead to a more favorable (i.e., more enjoyable) rebirth. In popular practice, the Buddha's nuanced teachings about karma have been simplified and commodified into a one-dimensional emphasis on generosity: by making offerings (usually food and money), especially to monastics and temples, you accumulate merit (Sanskrit punya, Pāli puñ̃a) that will improve your circumstances, if not in this life then in your next one. There is a curious parallel here with the commodification of sin that led to the sale of indulgences by the medieval Church: merit is positive, something to be sought, while sin is negative, something that needs to be absolved, yet in both cases the belief benefits the religious institution, which therefore has little incentive to correct it.

This shared preoccupation with what happens after we die should not, however, distract us from more important similarities between the pre-Christian Western philosophical traditions and the main teachings of Buddhism, regarding how to live now. In fact, the parallels are so striking that we are led to reflect on the possibility of historical influence, a topic that has recently received much scholarly attention. ${ }^{24}$ Because we normally describe Epicureanism, Stoicism, and Skepticism as philosophies, but view Buddhism as a religion, we do not usually think to compare them. Yet if we suspend any judgement about the transcendent nature of nirvana, the similarities become truly remarkable.

Buddhist teachings focus on two basic causes of dukkha (suffering): craving (Pali tanha, Sanskrit trisna) and ignorance (Pali avijja, Sanskrit avidya, literally "not seeing"). Tanha is the origin of dukkha, according to the second of the four noble truths believed to have been taught by the Buddha in his very first teaching

\footnotetext{
${ }^{23}$ In both the Alagadduupama Sutta and the Anuradha Sutta.

${ }^{24}$ See, in particular, McEvilley (2001).
} 
(as preserved as the Dhammacakkappavattana Sutta) after his awakening. The third noble truth asserts that there is an end to our dukkha (when our craving ceases), and the fourth noble truth gives the eightfold path that leads to its cessation: right view, right intention, right speech, right action, right livelihood, right effort, right mindfulness, and right concentration (or meditation).

Noticeably absent from this list is any reference to ascetic practices, which the Buddha reputedly tried before rejecting them in favor of mindfulness and meditation. The Buddhist path is a "middle way" between hedonism and asceticism, emphasizing not only ethical behavior but most of all realizing the way things really are (including oneself): hence the term enlightenment or, more literally, "awakening" ("the Buddha" means "the awakened one"). Although all eight parts of the path are important, there is nonetheless special emphasis on the last two, which involve the mind-control and personal transformation that is also the main focus of pre-Christian philosophies.

Other similarities with classical Epicureanism, Stoicism, and the Skepticism are hard to miss. The Buddhist path emphasizes nonattachment, so Buddhist monastics live according to rules that clearly regulate what they are allowed to own, and what desires they are able to satisfy. In the Theravada tradition, the basic possessions of monks are three robes, a belt, sewing needle, razor, and water filter; they may also have some incidentals such as toiletries (but not perfumes), a mosquito net, medicines, dharma books, etc. They are mendicant and beg for their food, normally eating only once a day, before noon. They must abstain from all sexual activity and intoxicants such as alcohol. Of course, this lifestyle assumes that, as Epicurus also realized, attempting to satisfy incessant desires is not the way to become truly happy.

Even as the Skeptics were concerned about the dogmatism of fixed views, so the Buddha emphasized that his teachings were heuristic: rather than offering a metaphysical position to identify with, they are helpful for discovering something for ourselves. Two well-known stories illustrate this. One tells of a dialogue between the Buddha and the monk Malunkyaputta, who is troubled by the Buddha's silence regarding fourteen questions, including the finitude or infinitude of the universe, and what happens to a Buddha after he dies. In response to his declaration that he will leave the monastic order if the Buddha does not answer his questions, the Buddha offers a parable:

Suppose, Mālunkyāputta, a man were wounded by an arrow thickly smeared with poison, and his friends and companions, his kinsmen and relatives, brought a surgeon to treat him. The man would say: 'I will not let the surgeon pull out this arrow until I know whether the man who wounded me was a noble or a brahmin or a merchant or a worker.' And he would say: 'I will not let the surgeon pull out this arrow until I know the name and clan of the man who wounded me; ... until I know whether the man who wounded me was tall or short or of middle height; ... until I know whether the bow that wounded me was a long bow or a crossbow...

The questions go on and on ...

All this would still not be known to that man and meanwhile he would die. So too, Mālunkyāputta, if anyone should say thus: 'I will not lead the holy life under the Blessed One until the Blessed One declares to me: "the world is eternal" ... or "after death a 
Tathāgata neither exists nor does not exist," that would still remain undeclared by the Tathāgata and meanwhile that person would die (Culamalunkya Sutta, Majjhima Nikaya $63)^{25}$

As Thich Nhat Hanh glosses, "The Buddha always told his disciples not to waste their time and energy in metaphysical speculation.... Life is short.",26

Even more famous is the simile comparing the Buddha's teaching to a raft that a man might use to cross a "great expanse of water, whose near shore was dangerous and fearful and whose further shore was safe and free from fear".

... Then, when he had got across and had arrived at the far shore, he might think thus: 'This raft has been very helpful to me, since supported by it and making an effort with my hands and feet, I got safely across to the far shore. Suppose I were to hoist it on my head or load it on my shoulder, and then go wherever I want.' Now, bhikkhus, what do you think? By doing so, would that man be doing what should be done with that raft?"

"No, venerable sir."

... 'Suppose I were to haul it onto the dry land or set it adrift in the water, and then go wherever I want.' Now, bhikkhus, it is by so doing that that man would be doing what should be done with that raft. So I have shown you how the Dhamma is similar to a raft, being for the purpose of crossing over, not for the purpose of grasping" (Alagadupama Sutta, Majjhima Nikaya 22). ${ }^{27}$

A common Zen metaphor admonishes us not to take the finger for the moon. The finger is pointing at something, which cannot be grasped conceptually. As the Skeptics might say, the goal is not to discover the correct view-a precise set of concepts - that we should fixate on, but to understand our inquiry as a path that seeks other beneficial effects.

Like Stoicism, Buddhism is particularly concerned about "afflictive emotions" (Sanskrit klesa, Pali kilesa) such as anger, pride, jealousy, and grief, which can lead us to act in ways that we regret later. The Buddha used the metaphor of two darts to emphasize the difference between pain and our emotional reaction to it:

When an untaught worldling is touched by a painful (bodily) feeling, he worries and grieves, he laments, beats his breast, weeps and is distraught. He thus experiences two kinds of feelings, a bodily and a mental feeling. It is as if a man were pierced by a dart and, following the first piercing, he is hit by a second dart... Having been touched by that painful feeling, he resists (and resents) it. ... He is fettered by suffering, this I declare.

But in the case of a well-taught noble disciple, $\mathrm{O}$ monks, when he is touched by a painful feeling, he will not worry nor grieve and lament, he will not beat his breast and weep, nor will he be distraught. It is one kind of feeling he experiences, a bodily one, but not a mental feeling. It is as if a man were pierced by a dart, but was not hit by a second dart following the first one.... Having been touched by that painful feeling, he does not resist (and resent) it. Hence, in him no underlying tendency of resistance against that painful feeling comes to underlie (his mind) Sallatha Sutta (Samyutta Nikaya 36.6). ${ }^{28}$

\footnotetext{
${ }^{25}$ The translation is from Bhikkhu Nanamoli and Bhikkhu Bodhi (1995), 534-35.

${ }^{26}$ Thich Nhat Hanh (1974), 42.

${ }^{27}$ See Bhikkhu Nanamoli and Bhikkhu Bodhi (1995), 228-29.

${ }^{28}$ The translation is from Bhikkhu Bodhi (2000), 1264-65.
} 
The issue of emotional reactions brings us back to the Buddha's understanding of karma, which emphasizes why we do what we do.

Although karma and rebirth were already widely accepted in pre-Buddhist India, Brahminical teachings understood karma mechanistically: performing a Vedic sacrifice in the proper fashion would sooner or later lead to the desired consequences. The Buddha transformed this ritualistic approach into a moral principle by focusing on cetana, which literally means "volitions" or "motivations." The beginning of the Dhammapada makes this point:

Experiences are preceded by mind, led by mind, and produced by mind. If one speaks or acts with an impure mind, suffering follows even as the cart-wheel follows the hoof of the ox.... If one speaks or acts with a pure mind, happiness follows like a shadow that never departs. $^{29}$

The term karma literally means "action." Focusing on the eventual consequences of our actions puts the cart (effect) before the horse (action), and loses the revolutionary implications of the Buddha's innovation. Emphasizing the initial act yields a different insight: that my life-situation can be transformed by transforming the motivations of my actions right now. Just as my body is composed of the food eaten and digested, so "I" am (re)constructed by my habitual mental attitudes. By choosing to change what motivates me, I can change the kind of person that I am.

Buddhist teachings say little about evil per se, but a lot about what are sometimes called the three "roots of evil" (also known as the three fires, or the three poisons) that often motivate our actions: greed, ill will, and delusion. We are encouraged to transform them into their positive counterparts: generosity, loving-kindness, and the wisdom that realizes our interdependence with others.

From this perspective, karma does not need to be taken as a cosmological law comparable to Newton's second law of motion. It can be understood more psychologically, in a way that accords with Stoic insights into the happiness of a virtuous life: we experience karmic consequences not so much for what we have done as for what we have become, because what we intentionally and habitually do make us what we are: I become the kind of person who does that sort of thing. In other words, we are "punished" not for our "sins" but by them. And from the other side, as Spinoza declares at the end of the Ethics: happiness is not the reward of virtue, but is virtue itself (Ethics, Part V, Proposition XLII).

In other words, to be motivated differently is to become a different kind of person, and to become a different kind of person is to experience the world in a different way. When we respond differently to the challenges and opportunities the world presents to us, the world tends to respond differently to us, because our ways of acting involve feedback systems that incorporate other people. The more I am motivated by greed, ill will, and delusion, the more I must manipulate the world to get what I want, and consequently the more separate I feel from others, and the more alienated others feel when they realize what is happening.

\footnotetext{
${ }^{29}$ Dhammapada (2010).
} 
On the other side, the more my actions are motivated by generosity, loving-kindness, and the wisdom that acknowledges our interdependence, the more I can relax and open up to the world. The more I feel genuinely connected with other people, the less I will be inclined to use and abuse them, and consequently the more inclined they will be to trust and open up to me. In such ways, transforming my own motivations not only transforms my own life; it also tends to affect those around me, since, as Buddhism emphasizes, we are not really separate.

This naturalistic understanding of karma does not exclude the possibility of more mysterious possibilities regarding the consequences of our actions, such as their effects on one's rebirth, as traditional Buddhism emphasizes. Whether or not that happens, however, karma as how-to-transform-my-life-situation-by-transformingmy-motivations-right-now is not a fatalistic doctrine but an empowering teaching, with many similarities to pre-Christian philosophies of life. Instead of passively accepting the problematic circumstances of our lives, we are encouraged to improve our situations by addressing them with generosity, loving-kindness and wisdom.

Of course, this approach does not make me invulnerable to external events beyond my control, but focuses instead on training my mental ability to respond to them. Whether or not karma is a cosmic law, whether or not there is rebirth, whether or not nirvana transcends the reality of this world, such teachings have enormous implications for how happily we are able to live here and now, day-to-day.

\section{Protection Against Luck: West and East}

'Luck' or 'chance' on the one hand, and 'karma' on the other seem, at first glance, opposing concepts. If something happens by luck, it is beyond the agent's control. Hence, the main concern of some ancient philosophical schools has been to make our happiness immune against luck. Karma, however, implies that the agent has a great deal of (indirect) control over what happens to her. Thus, luck or chance has been eliminated. Yet, as this chapter has attempted to demonstrate, ancient grapplings with luck and Buddhist discussions about karma, respectively, address the same salient concerns of human existence. What should we do in order to become happy, or, approaching the same question from the other side of the spectrum, what should we do to end our suffering? Both philosophical traditions indicate ways of how we should respond to oscillations of our experience, caused by internal and external events that seem beyond our control. Both philosophical traditions believe that the invulnerability of our happiness against luck depends upon a mental transformation. The Western tradition has focused more on coping with the emotional effects of bad luck: disappointed desires and expectations, anger, fear, anxiety, grief. The Buddhist tradition, on the other hand, has focused its mental training much more on the agent's motivations. Even though these approaches are quite different, the curative methods offered are aimed to change our experience of the world and are still helpful today in our attempts to secure happiness in the face of chance adversity. 
Open Access This chapter is distributed under the terms of the Creative Commons Attribution-Noncommercial 2.5 License (http://creativecommons.org/licenses/by-nc/2.5/) which permits any noncommercial use, distribution, and reproduction in any medium, provided the original author(s) and source are credited. The images or other third party material in this chapter are included in the work's Creative Commons license, unless indicated otherwise in the credit line; if such material is not included in the work's Creative Commons license and the respective action is not permitted by statutory regulation, users will need to obtain permission from the license holder to duplicate, adapt or reproduce the material.

\section{References}

Annas, J. (1993). The morality of happiness. Oxford: Oxford University Press.

Aristotle (2002) Nicomachean ethics. Translation (with historical introduction) by Christopher Rowe; Philosophical introduction and commentary by Sara Broadie. Oxford: Oxford University Press.

Brown, P. (1969). Augustine of Hippo: A biography. Berkeley: University of California Press.

Carpenter, A. D. (2014). Indian Buddhist philosophy. London: Routledge.

Chadwick, H. (2009). Augustine of Hippo: A life. Oxford: Oxford University Press.

The Connected Discourses of the Buddha (2000). A Translation of the Samyutta Nikaya by Bhikkhu Bodhi. Somerville, MA.

Cooper John, M. (2012). Pursuits of wisdom: Six ways of life in Ancient philosophy from Socrates to Plotinus. Princeton: Princeton University Press.

Dhammapada: The Way of Truth (2010). Translated from the Pali by Sangharakshita. Cambridge, UK: Windhorse.

Epictetus (1995). The discourses, the handbook, the fragments. In C. Gill, (Ed.), (Trans. revised R. Hard). London.

Garfield, J. L. (2015). Engaging Buddhism. Why it matters to philosophy. Oxford: Oxford University Press.

Hadot, P. (2002). Exercises spirituels et philosophie antique. Paris: Albin Michel.

Hadot, P. (1995). Qu'est-ce que la philosophie antique? Paris: Gallimard.

Hadot, P. (2002). What is Ancient philosophy (M. Chase, Trans.). Cambridge, MA.

Harvey, P. (2013). An introduction to Buddhism. Teachings, history and practices (2nd ed.). Cambridge: Cambridge University Press.

Long, A. A. (2006). From Epicurus to Epictetus: Studies in Hellenistic and Roman philosophy. Oxford: Clarendon Press.

Long, A. A. (2001). Philosophy's hardest question: "What to make of oneself?". Representations, $74,19-36$.

Long, A. (1996). Stoic studies. Cambridge: Cambridge University Press.

Loy, D. R. (2008). How to drive your Karma. In Money, Sex, War, Karma. Notes for a Buddhist revolution (pp. 53-65). Boston: Wisdom Publications.

McEvilley, T. (2001). The shape of Ancient thought: Comparative studies in Greek and Indian philosophies. New York: Allworth Press.

Nelson, D. R. (2011). Sin: A guide for the Perplexed. London: T\&T Clark.

The Middle Length Discourses of the Buddha (1995). (B. Nanamoli \& B. Bodhi, Trans.). Boston: Wisdom Publications.

Mikalson, J. D. (2002). The daimon of eudaimonia. In J. F. Miller, C. Damon \& K. S. Myers (Eds.), Vertis in Usum: Studies in honor of Edward Courtney (pp. 250-259). München: K.G. Saur.

Nisula, T. (2012). Augustine and the functions of concupiscence. Leiden: Brill.

Nussbaum, M. C. (1986). The Fragility of goodness. Luck and ethics in Greek tragedy and philosophy. Cambridge: Cambridge University Press. 
Nussbaum, M. C. (1994). The therapy of desire. Theory and practice in Hellenistic ethics. Princeton: Princeton University Press.

Rist, J. M. (1994). Augustine: Ancient thought baptized. Cambridge: Cambridge University Press.

Sedley, D. (1999). The ideal of godlikeness. In G. Fine (Ed.), Plato 2: Ethics, Politics, Religion and the Soul (pp. 309-328). Oxford: Oxford University Press.

Sextus Empiricus Outlines of scepticism (1994). (J. Annas \& J. Barnes, Trans.). Cambridge.

Sorabji, R. (2000). Emotion and peace of mind: From Stoic agitation to Christian temptation. Oxford: Oxford University Press.

Thich Nhat Hanh (1974). Zen keys. New York: Anchor Press.

Tsouma, V. (2009). Epicurean therapeutic strategies. In J. Warren (Ed.), The Cambridge companion to Epicureanism (pp. 249-265). Cambridge: Cambridge University Press.

Van Oort, J. (1991). Jerusalem and Babylon. A study into Augustine's City of God and the sources of his doctrine of the two cities. Leiden: Brill.

Warren, J. (2009). Removing fear. In J. Warren (Ed.), The Cambridge companion to Epicureanism (pp. 234-248). Cambridge: Cambridge University Press.

Williams, B. A. O. (2006). The legacy of Greek philosophy. In B. Williams (Ed.), The sense of the past. Essays in the history of philosophy; Edited with an introduction by Myles Burnyeat. Princeton and Oxford: Princeton University Press. 